\title{
Large Individual Differences in Serum 25-Hydroxy- vitamin D Response to Vitamin D Supplementation: Effects of Genetic Factors, Body Mass Index, and Baseline Concentration. Results from a Randomized Controlled Trial
}

Authors

Affiliations

\author{
S. T. Sollid ${ }^{1,2}$, M. Y. S. Hutchinson ${ }^{1,3}$, O. M. Fuskevåg ${ }^{4}$, R. M. Joakimsen ${ }^{1,2}$, R. Jorde ${ }^{1,2}$
}

Tromsø Endocrine Research Group, Department of Clinical Medicine, UiT The Arctic University of Norway, Tromsø, Norway Division of Internal Medicine, University Hospital of North Norway, Tromsø, Norway

Division of Rehabilitation Services, University Hospital of North Norway, Tromsø, Norway

${ }^{4}$ Division of Diagnostic Services, University Hospital of North Norway, Tromsø, Norway
Key words

- serum 25-hydroxyvitamin D

vitamin D supplementation

genetic factors received 23.09.2014 accepted 07.01.2015

\section{Bibliography}

DOI http://dx.doi.org/ 10.1055/s-0034-1398617

Published online:

February 19, 2015

Horm Metab Res 2016;

48: 27-34

(c) Georg Thieme Verlag KG

Stuttgart · New York

ISSN 0018-5043

\section{Correspondence}

\section{S. T. Sollid, MD}

Division of Internal Medicine University Hospital of North Norway

9038 Tromsø

Norway

Tel.: + 47/77/628 246

Fax: $+47 / 77 / 669730$

stina.therese.sollid@unn.no

\section{Abstract}

\section{$\nabla$}

The main aim of the study was to determine the influence of genetic factors on the serum 25-hydroxyvitamin D response to vitamin D supplementation. The main outcome measure was an increase in serum 25-hydroxyvitamin D after vitamin D supplementation. The patients are part of a randomized controlled trial in individuals with prediabetes assigned to $20000 \mathrm{IU}$ of vitamin $\mathrm{D}_{3}$ per week or placebo for 12 months. A total of 484 subjects were included in the analyses and genotyped for single nucleotide polymorphisms in the DBP, DHCR7, CYP2R1, and CYP24A1 genes. Single nucleotide polymorphisms from all 4 selected genes were significantly related to baseline serum 25-hydroxyvitamin D concentrations with differences between major and minor homozygote genotypes ranging from 4.4 to $19.2 \mathrm{nmol} / \mathrm{l}$. In the subjects given vitamin $\mathrm{D}$, those with genotypes with the highest baseline 25-hydroxyvitamin D

\section{Introduction}

\section{$\nabla$}

The nuclear vitamin D receptor (VDR) is found in cells in a number of tissues, and the enzyme necessary for the activation of 25-hydroxyvitamin $D$ [25(OH)D] to the active form 1,25-dihydroxyvitamin $\mathrm{D}\left[1,25(\mathrm{OH})_{2} \mathrm{D}\right]$ is present also in extrarenal tissues [1]. Accordingly, vitamin D is likely to be important for more than skeletal health, and low serum 25(OH)D levels, used to evaluate a subject's vitamin D status, are associated with a number of adverse health outcomes [2]. Recent guidelines recommend serum levels of at least $50-75 \mathrm{nmol} / 1[3,4]$, and if so, billions of people are vitamin $\mathrm{D}$ deficient and in need of vitamin $\mathrm{D}$ supplementation [5].

However, there are several reports on a U- or J-shaped relation between serum 25(OH)D levels and health effects [6-8], with an optimal serum concentration also had the highest 25-hydroxyvitamin D concentration after 12 months, and the increase (delta) in 25-hydroxyvitamin D was significantly related to 3 of the single nucleotide polymorphisms. The increase in serum 25-hydroxyvitamin D was also higher in lean vs. obese subjects, and higher in those with low baseline 25-hydroxyvitamin D concentrations. When combining these 3 factors in a linear regression model, the predicted (and observed) difference in 25-hydroxyvitamin D increase between high and low responders to the supplementation was approximately $60 \mathrm{nmol} / \mathrm{l}$. In conclusion, due to genetic, body mass, and baseline 25-hydroxyvitamin D differences, there are huge individual variations in the serum 25-hydroxyvitamin $\mathrm{D}$ response to vitamin D supplementation that could be of clinical importance.

Supporting Information for this article is available online at http://www.thieme-connect.de/products

$25(\mathrm{OH}) \mathrm{D}$ level of $50-60 \mathrm{nmol} / \mathrm{l}$ in one study [8] When giving recommendations for vitamin $\mathrm{D}$ supplementation to the general public, it is therefore important to know not only if there are subgroups in need of higher doses than average, but also if there are subgroups where the increase in serum 25(OH)D will be particularly high. Individual factors affect the $25(\mathrm{OH}) \mathrm{D}$ response to vitamin D supplementation, and obese subjects need higher doses to achieve a desired increase $[9,10]$. Genetic factors may also be important, and genome wide association studies (GWAS) have shown that single nucleotide polymorphisms (SNPs) in the vitamin D binding protein (DBP), as well as in enzymes necessary for activation or degradation of vitamin $\mathrm{D}$ and its metabolites, affect serum 25(OH)D concentration [11,12]. So far most studies on 25(OH)D response to vitamin D have been dose-response studies. Few 
studies have included genetic and other factors in the analyses [13-15], and the results have not been conclusive. We are presently performing a large randomized controlled trial (RCT) with vitamin $\mathrm{D}$ where we have relevant genetic and background data available, as well as the one year $25(\mathrm{OH}) \mathrm{D}$ responses, and therefore had the opportunity to address these questions.

\section{Materials and Methods}

$\nabla$

\section{Study design}

The design of the study and the study population have been described in detail previously [16]. Briefly, the subjects are participants in an ongoing RCT with vitamin D vs. placebo in subjects with prediabetes that runs over 5 years with annual oral glucose tolerance tests. 5 hundred and eleven subjects entered the study at baseline, 256 received $20000 \mathrm{IU}$ of vitamin $\mathrm{D}_{3}$ (Dekristol, Mibe, Jena, Germany) per week and 255 received placebo capsules that looked identical (Hasco-lek, Wroclaw, Poland). Thirty capsules were supplied at baseline and after 6 months to ensure sufficient supply if a visit had to be delayed. Unused medication was returned and counted. Compliance rate (\%) was calculated as the ratio between capsules used/study weeks. In this calculation, those who had used more capsules than the intended one per week (based in the number of capsules returned) had their compliance set to $100 \%$.

The subjects included had to be between age $21-80$ years and have impaired fasting glucose (IFG) and/or impaired glucose tolerance (IGT) as defined by World Health Organization [17]. Exclusion criteria were primary hyperparathyroidism, sarcoidosis or other granulomatous disorders, urolithiasis, cancer during the 5 last years, reduced kidney function, or unstable angina pectoris, acute myocardial infarction or stroke in the last year. Fertile women had to use contraception, could not be pregnant or be lactating. The subjects were not allowed to take vitamin $\mathrm{D}$ supplements (including cod liver oil) exceeding $400 \mathrm{IU} /$ day during the study. A sum of 484 subjects came to the one-year visit and were included in the present study.

In order to ensure that all investigators remained blinded, all data were sent directly to the Hospital's Research Department where the data files were merged and coupled to the randomization code. The Research Department then sent the final file without person identification to the principal investigators (S.T.S. and R.J.).

Fasting serum samples were drawn at baseline and after 12 months. Previously the measurements of serum levels of $25(\mathrm{OH})$ $\mathrm{D}$, serum calcium, parathyroid hormone (PTH), and HbA1c have been described $[16,18]$. Height and weight were measured wearing light clothing and no shoes. Body mass index (BMI) was calculated as weight $(\mathrm{kg})$ divided by squared height $\left(\mathrm{m}^{2}\right)$. Questionnaires on intake of vitamin D supplements including cod liver oil and calcium supplements were filled in at baseline and after 12 months.

\section{Selection of SNPs for analysis}

The serum 25(OH)D concentrations are related to SNPs in the $D B P$ gene ( $D B P$ or $G C$ ) responsible for binding and transportation of vitamin $\mathrm{D}$ metabolites in the circulation, in the 7-dehydrocholesterol (7-DHC) reductase gene (DHCR7) responsible for the availability of vitamin D precursor 7-DHC in the skin, in the 25-hydroxylase gene (CYP2R1) involved in the conversion of vitamin $\mathrm{D}$ into $25(\mathrm{OH}) \mathrm{D}$ in the liver, and in the 24-hydroxylase gene (CYP24A1) involved in the degradation of 25(OH)D [19]. To avoid problems with multiple testing, we selected one SNP in each of these genes and chose the one with the highest difference in serum 25(OH)D between the major and minor homozygote genotype (rs2282679, rs3829251, rs10741657, rs6013897, respectively) as reported in our previous studies [14]. In addition, we included two SNPs in the DBP gene (rs7041 and rs4588) since reference to these two SNPs are frequently made in relation to serum 25(OH)D levels $[11,12,20]$. Blood samples for SNP analyses were sent to KBiosciences (http://www.lgcgenomics. com/genotyping/) and all genotyping were performed with a competitive allele-specific polymerase chain reaction (KASPar) assay that enables highly accurate bi-allelic scoring of SNPs.

\section{Statistical analyses}

Normal distribution was evaluated by means of KolmogorovSmirnov test and Q-Q plots. Serum PTH was not normally distributed and was log-transformed when used in the statistical analyses. Data are presented as mean \pm SD for normally distributed variables and as median $\left(2.5^{\text {th }}, 97.5^{\text {th }}\right.$ percentiles $)$ for nonnormally distributed variables. Trends across the genotypes were evaluated using linear regression with age, sex, and BMI as covariates. For the baseline values, season (summer (May-September)/ winter (October-April)) and intake of vitamin D supplements (including cod liver oil), were also included as covariates.

The genotype frequencies were examined for compliance with Hardy-Weinberg equilibrium using $x^{2}$ analysis [21]. The linkage disequilibrium (LD) between SNPs was evaluated with $\mathrm{r}^{2}$ using CubeX calculations with $\mathrm{r}^{2} \geq 0.4$ as a cutoff for LD [22]. Level of significance was set at $\mathrm{p}<0.05$ (two-tailed). All statistical analyses were performed using IBM SPSS Statistics version 21.

\section{Ethics}

The study was approved by the Norwegian Medicines Agency and by the Regional Committee for Medical Research Ethics. The trial including the genetic analyses was registered at ClinicalTrials.gov (NCT00685594). However, the analysis of serum $25(\mathrm{OH})$ $\mathrm{D}$ response to supplementation in relation to genetic polymorphisms was not explicitly pre-specified.

\section{Results}

$\nabla$

The two DBP SNPs rs2282679 and rs4588 were in LD with each other $\left(r^{2}=0.98\right)$, and rs4588 was therefore not included in further analyses. None of the other SNPs were in LD, and all SNPs were in Hardy-Weinberg equilibrium, $X^{2}$ testing; $p>0.05$. There were no reports or observations of serious adverse events during the one-year study period.

\section{Baseline 25(OH)D levels}

The baseline characteristics of the 484 subjects are presented in 0 Table 1, the vitamin $D$ and placebo groups did not differ significantly. As expected the serum 25(OH)D levels were higher during the summer than the winter months, $64.8 \mathrm{nmol} / 1 \pm 22.0$ vs. $57.3 \mathrm{nmol} / \mathrm{l} \pm 20.6, \mathrm{p}<0.001$, and females had higher $25(\mathrm{OH}) \mathrm{D}$ concentrations than males, $64.5 \mathrm{nmol} / 1 \pm 22.6$ vs. $58.4 \mathrm{nmol} /$ $1 \pm 20.6, p<0.01$. The serum $25(\mathrm{OH}) \mathrm{D}$ concentrations were only slightly, and nonsignificantly, higher in those using vitamin D supplementation vs. those not using supplements, $62.0 \mathrm{nmol} /$ $1 \pm 19.3$ vs. $60.0 \mathrm{nmol} / 1 \pm 22.5$. The distributions in baseline concentration are shown in $\odot$ Fig. 1. 


\begin{tabular}{|c|c|c|c|}
\hline \multirow[t]{2}{*}{ Variables } & \multirow[t]{2}{*}{ All } & \multicolumn{2}{|c|}{ Randomization status } \\
\hline & & Vitamin D & Placebo \\
\hline Male/Female & $298 / 186$ & $152 / 90$ & 146/96 \\
\hline Age (years) & $62.0 \pm 8.6$ & $62.1 \pm 8.2$ & $62.0 \pm 9.1$ \\
\hline $\operatorname{BMI}\left(\mathrm{kg} / \mathrm{m}^{2}\right)$ & $29.9 \pm 4.3$ & $30.1 \pm 4.1$ & $29.8 \pm 4.4$ \\
\hline $\mathrm{HbA1c}(\mathrm{mmol} / \mathrm{mol})^{*}$ & $41.8 \pm 3.4$ & $41.9 \pm 3.3$ & $41.7 \pm 3.5$ \\
\hline Serum 25(OH)D $(\mathrm{nmol} / \mathrm{l})^{\dagger}$ & $60.7 \pm 21.6$ & $59.8 \pm 21.9$ & $61.6 \pm 21.2$ \\
\hline Serum calcium $(\mathrm{mmol} / \mathrm{l})^{\ddagger}$ & $2.31 \pm 0.08$ & $2.31 \pm 0.07$ & $2.31 \pm 0.08$ \\
\hline Serum PTH $(\mathrm{pmol} / \mathrm{l})^{\S}$ & $5.68 \pm 2.23$ & $5.78 \pm 2.29$ & $5.58 \pm 2.17$ \\
\hline $\begin{array}{l}\text { Daily vitamin D supplementation (no of subjects/mean } \\
\text { dose in IU for subjects taking supplements) }{ }^{*}\end{array}$ & $163 / 335 \pm 153$ & $77 / 310 \pm 127$ & $86 / 358 \pm 170$ \\
\hline $\begin{array}{l}\text { * Data missing for } 8 \text { subjects ( } 6 \text { in the vitamin } D \text { group and } 2 \\
\text { † Data missing for } 2 \text { subjects ( } 1 \text { in both the vitamin D group a a } \\
\ddagger \text { Data missing for } 1 \text { subject in the placebo group } \\
{ }^{\S} \text { Data missing for } 5 \text { subjects ( } 2 \text { in the vitamin D group and } 3\end{array}$ & $\begin{array}{l}\text { the placebo group) } \\
\text { the placebo group) } \\
\text { the placebo group) }\end{array}$ & & \\
\hline
\end{tabular}

Table 1 Baseline characteristics in all subjects and in relation to randomization status.

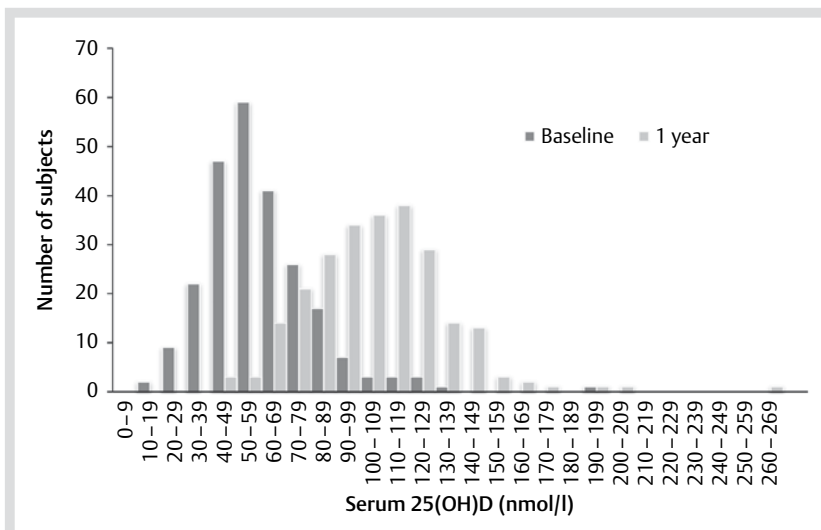

Fig. 1 The distribution in baseline and in 12 month serum 25(OH)D concentration in subjects randomized to vitamin $\mathrm{D}$.

For all five SNPs there was a significant effect of genotype on the serum 25(OH)D concentration with the difference between major and minor homozygote genotypes ranging from 4.4 to $19.2 \mathrm{nmol} / \mathrm{l}$ (Supplemental Table S1). None of the SNPs were related to sex, age, BMI, or serum calcium (Supplemental Table S1). However, there was a significant relation between rs6013897 and PTH, with the highest serum PTH in the subjects with the minor homozygote genotype who also had the lowest serum 25(OH)D (Supplemental Table S1). This significant relation between rs6013897 and PTH was also seen in the subjects given vitamin D after 1 year (data not shown).

\section{Serum 25(OH)D levels after one year}

The mean compliance rate in both the vitamin $\mathrm{D}$ and the placebo groups was $97.5 \%$. Subjects in the vitamin D group had a significant increase in mean serum 25(OH)D from baseline levels of $59.8 \mathrm{nmol} / 1 \pm 21.9$ to $105.6 \mathrm{nmol} / 1 \pm 27.7$ after 12 months ( $\odot$ Table 2); however, still $12.4 \%$ had serum $25(\mathrm{OH}) \mathrm{D}$ levels $<75 \mathrm{nmol} / \mathrm{l}$ and a large spread in 12 month and delta 25(OH)D concentrations were seen ( $\bullet$ Fig. 1,2). In the placebo group, the serum 25(OH)D concentrations did not change significantly (Supplemental Table S2).

\section{Effect of genotype on serum 25(OH)D concentrations} after one year

The increase in serum 25(OH)D in the vitamin D group was highly dependent on genotype. For all the five SNPs the genotype with the highest baseline $25(\mathrm{OH}) \mathrm{D}$ concentration also had the highest 25( $\mathrm{OH}) \mathrm{D}$ concentration after 12 months, and for 4 of the SNPs the difference in $25(\mathrm{OH}) \mathrm{D}$ between the major and minor homozygote genotypes increased (range 15.9-28.2 nmol/l) after vitamin D supplementations ( Table 2). For 3 of the SNPs (rs2282679, rs7041, and rs10741657) there was a significant relation between genotype and increase (delta) in $25(\mathrm{OH}) \mathrm{D}$ with differences between major and minor homozygote in delta 25(OH)D being $6.3,11.9$ and $13.8 \mathrm{nmol} / \mathrm{l}$, respectively ( $\odot$ Table 2 ).

Effect of sex, age, BMI, and baseline 25(OH)D on serum 25(OH)D after vitamin D supplementation

At baseline females had significantly higher 25(OH)D concentration than males, but they had an almost identical increase in serum 25(OH)D after 12 months ( $\odot$ Table 2). There was a clear relation between age and serum $25(\mathrm{OH}) \mathrm{D}$ at baseline with the highest concentration in the oldest subjects. The same was seen if excluding subjects taking vitamin D supplements (data not shown). However, the increase in serum 25(OH)D appeared unrelated to age ( $\odot$ Table 2 ).

There was a significant and inverse relation between BMI and increase in 25(OH)D concentration after supplementation. In spite of $6.9 \mathrm{nmol} / 1$ higher baseline $25(\mathrm{OH}) \mathrm{D}$ levels, subjects with $\mathrm{BMI}<25 \mathrm{~kg} / \mathrm{m}^{2}$ had a $18.6 \mathrm{nmol} / \mathrm{l}$ higher increase in $25(\mathrm{OH}) \mathrm{D}$ than subjects with BMI $>35 \mathrm{~kg} / \mathrm{m}^{2}$ ( $\odot$ Table 2 ).

Subjects with the lowest baseline concentration of 25(OH)D had the highest increase in serum 25(OH)D ( $\odot$ Table 2 ). Thus, subjects with baseline serum 25(OH)D concentration $<40 \mathrm{nmol} / \mathrm{l}$ had a $24.1 \mathrm{nmol} / 1$ higher increase in $25(\mathrm{OH}) \mathrm{D}$ than those with baseline serum $25(\mathrm{OH}) \mathrm{D}>75 \mathrm{nmol} / \mathrm{l}$. However, after 12 months supplementation with vitamin $\mathrm{D}$ their mean serum $25(\mathrm{OH}) \mathrm{D}$ levels were still $36.6 \mathrm{nmol} / 1$ lower compared to those with baseline serum 25(OH)D > $75 \mathrm{nmol} / \mathrm{l}$ ( $\bullet$ Table 2).

Accordingly, in a multiple linear regression model with age, BMI, sex, and baseline serum 25(OH)D levels as covariates, only BMI and baseline $25(\mathrm{OH}) \mathrm{D}$ concentration were significant and negative predictors of increase in serum 25(OH)D. There was no effect of calcium supplementation on the serum $25(\mathrm{OH}) \mathrm{D}$ increase (data not shown).

\section{Relation between baseline and 1 year serum 25(OH)D levels in those given placebo}

There was a high correlation between baseline and 12 months serum 25(OH)D concentrations in those given placebo $(r=0.70$, $\mathrm{p}<0.001$ ) (data not shown), but a clear regression towards the 


\begin{tabular}{|c|c|c|c|c|}
\hline Variables & n & $\begin{array}{l}\text { Baseline serum } \\
\text { 25(OH)D (nmol/I) }\end{array}$ & $\begin{array}{l}\text { 12-Month serum } \\
\text { 25(OH)D (nmol/l) }\end{array}$ & $\begin{array}{l}\text { Delta serum 25(OH)D } \\
\text { (nmol/l) }\end{array}$ \\
\hline \multicolumn{5}{|l|}{ SNP genotypes } \\
\hline \multicolumn{5}{|l|}{ rs2282679 } \\
\hline Major homozygote & 150 & $63.0 \pm 23.1^{*}$ & $112.7 \pm 28.8^{*}$ & $50.0 \pm 25.4^{*}$ \\
\hline Heterozygote & 77 & $57.4 \pm 19.0$ & $95.9 \pm 21.9$ & $38.5 \pm 21.0$ \\
\hline Minor homozygote & 15 & $40.8 \pm 10.6$ & $84.5 \pm 15.8$ & $43.7 \pm 16.6$ \\
\hline \multicolumn{5}{|l|}{ rs $7041^{\ddagger}$} \\
\hline Major homozygote & 77 & $62.6 \pm 25.4^{*}$ & $117.0 \pm 30.9^{*}$ & $54.4 \pm 26.5^{*}$ \\
\hline Heterozygote & 117 & $61.4 \pm 20.5$ & $103.0 \pm 25.3$ & $41.8 \pm 22.8$ \\
\hline Minor homozygote & 47 & $50.8 \pm 16.4$ & $93.2 \pm 20.9$ & $42.5 \pm 20.0$ \\
\hline \multicolumn{5}{|l|}{ rs3829251§ } \\
\hline Major homozygote & 134 & $63.2 \pm 23.5^{*}$ & $108.2 \pm 28.9^{\dagger}$ & $45.0 \pm 23.8$ \\
\hline Heterozygote & 84 & $55.4 \pm 19.5$ & $101.6 \pm 25.4$ & $46.5 \pm 23.6$ \\
\hline Minor homozygote & 18 & $55.4 \pm 18.2$ & $102.7 \pm 23.3$ & $47.3 \pm 24.6$ \\
\hline \multicolumn{5}{|l|}{ rs10741657 } \\
\hline Major homozygote & 77 & $57.4 \pm 25.5$ & $100.1 \pm 30.4^{*}$ & $42.7 \pm 23.2^{*}$ \\
\hline Heterozygote & 119 & $60.6 \pm 18.9$ & $104.2 \pm 22.7$ & $43.8 \pm 20.9$ \\
\hline Minor homozygote & 47 & $61.7 \pm 22.7$ & $118.2 \pm 31.1$ & $56.5 \pm 30.1$ \\
\hline \multicolumn{5}{|l|}{ rs6013897II } \\
\hline Major homozygote & 138 & $62.6 \pm 23.0^{*}$ & $108.1 \pm 30.3^{*}$ & $45.8 \pm 24.9$ \\
\hline Heterozygote & 88 & $57.2 \pm 20.9$ & $103.7 \pm 24.1$ & $46.4 \pm 23.4$ \\
\hline Minor homozygote & 14 & $50.2 \pm 11.9$ & $92.2 \pm 18.8$ & $42.0 \pm 22.0$ \\
\hline \multicolumn{5}{|l|}{ Sex } \\
\hline Male & 152 & $58.2 \pm 22.8^{\dagger}$ & $104.0 \pm 28.6$ & $45.8 \pm 25.9$ \\
\hline Female & 90 & $62.6 \pm 20.2$ & $108.4 \pm 26.1$ & $46.2 \pm 25.9$ \\
\hline \multicolumn{5}{|l|}{ Age group } \\
\hline$<50$ years & 22 & $51.5 \pm 18.9^{*}$ & $95.3 \pm 27.8$ & $43.8 \pm 27.7$ \\
\hline $50-59$ years & 50 & $56.0 \pm 21.4$ & $106.9 \pm 26.8$ & $50.9 \pm 26.0$ \\
\hline $60-69$ years & 133 & $60.4 \pm 21.9$ & $106.3 \pm 28.5$ & $46.1 \pm 23.0$ \\
\hline$>70$ years & 37 & $67.9 \pm 22.1$ & $107.8 \pm 25.6$ & $39.8 \pm 22.5$ \\
\hline \multicolumn{5}{|l|}{ BMI group } \\
\hline$<25 \mathrm{~kg} / \mathrm{m}^{2}$ & 23 & $59.0 \pm 14.9$ & $119.3 \pm 34.3^{*}$ & $60.4 \pm 32.9^{\dagger}$ \\
\hline $25-29.9 \mathrm{~kg} / \mathrm{m}^{2}$ & 110 & $59.7 \pm 21.5$ & $106.9 \pm 25.1$ & $47.5 \pm 24.2$ \\
\hline $30-34.9 \mathrm{~kg} / \mathrm{m}^{2}$ & 78 & $63.2 \pm 24.5$ & $104.4 \pm 29.4$ & $41.2 \pm 21.7$ \\
\hline$>35 \mathrm{~kg} / \mathrm{m}^{2}$ & 31 & $52.1 \pm 19.6$ & $93.9 \pm 22.5$ & $41.8 \pm 17.3$ \\
\hline \multicolumn{5}{|l|}{ Baseline 25(OH)D } \\
\hline$<40 \mathrm{nmol} / \mathrm{l}$ & 33 & $32.0 \pm 6.3$ & $90.5 \pm 26.8$ & $58.5 \pm 26.5^{*}$ \\
\hline $40-49 \mathrm{nmol} / \mathrm{l}$ & 47 & $44.9 \pm 3.2$ & $91.9 \pm 18.0$ & $47.0 \pm 17.8$ \\
\hline $50-74 \mathrm{nmol} / \mathrm{l}$ & 114 & $60.4 \pm 6.8$ & $107.1 \pm 23.9$ & $46.6 \pm 24.0$ \\
\hline$>75 \mathrm{nmol} / \mathrm{l}$ & 47 & $92.7 \pm 21.6$ & $127.1 \pm 30.9$ & $34.4 \pm 23.6$ \\
\hline \multicolumn{5}{|c|}{${ }^{*} \mathrm{p}<0.01$ and $^{\dagger} \mathrm{p}<0.05$} \\
\hline \multicolumn{5}{|c|}{$\begin{array}{l}\text { Baseline: Linear trend across the genotypes with sex, age, BMI, season, and intake of vitamin D supplementation as covariates. Twelv } \\
\text { month and delta values: Linear trend across the genotypes with sex, age, and BMI as covariates. Normally distributed data are pre- } \\
\text { sented as means } \pm \text { SD }\end{array}$} \\
\hline
\end{tabular}

Table 2 Serum 25(OH)D at baseline, 12-month, and delta values in relation to vitamin $\mathrm{D}$ SNP genotypes, sex, age, BMI, and baseline 25(OH)D categories in subjects randomized to vitamin $\mathrm{D}$ supplementation. mean with an increase of $8.6 \mathrm{nmol} / \mathrm{l}$ in serum 25(OH)D in those with baseline serum $25(\mathrm{OH}) \mathrm{D}<40 \mathrm{nmol} / 1$ and a decrease in serum $25(\mathrm{OH}) \mathrm{D}$ of $7.9 \mathrm{nmol} / \mathrm{l}$ in those with baseline serum 25(OH)D > $75 \mathrm{nmol} / \mathrm{l}$ (Supplemental Table S2).

\section{Prediction of change in serum 25(OH)D concentration based on baseline 25(OH)D concentration, baseline $\mathrm{BMI}$, and genotype}

To predict change in serum 25(OH)D concentration based on baseline 25(OH)D concentration, baseline BMI, and genotype, we set up a regression equation with randomization status, baseline BMI and baseline serum 25(OH)D and the three SNPs that in the model were significant (rs2282679, rs7041, and rs10741657) and interaction terms between each of the three SNPs with the randomization status: delta $25(\mathrm{OH}) \mathrm{D}=$ inter- cept $+(\beta$-randomization status $\times$ randomization status $)+[\beta$ baseline $25(\mathrm{OH}) \mathrm{D} \times$ baseline $25(\mathrm{OH}) \mathrm{D}]+(\beta$-baseline $\mathrm{BMI} \times$ baseline $\mathrm{BMI})+(\beta$-rs2282679 $\times$ rs2282679 $)+(\beta-\mathrm{rs} 10741657 \times$ rs10$741657)+(\beta$-rs7041 $\times$ rs7041 $)+[$ randomization status $\times$ baseline BMI $\times(\beta$-randomization status $\times$ rs2282679 $)]+[$ randomization status $\times$ baseline $\mathrm{BMI} \times(\beta$-randomization status $\times$ rs 10741657)]+ [randomization status $\times$ baseline BMI $\times(\beta$-randomization status $\times$ rs7041)]. Sex and age did not significantly influence delta $25(\mathrm{OH}) \mathrm{D}$ and were therefore not included in the equation.

The resulting delta 25(OH)D responses according to baseline vitamin D status and BMI and "best" [associated with highest increase in serum $25(\mathrm{OH}) \mathrm{D}$ ] and "worst" [associated with the lowest increase in serum $25(\mathrm{OH}) \mathrm{D}$ ] genotypes are shown in $\odot$ Table 3. As an example of extreme difference in response, a lean person with BMI $22 \mathrm{~kg} / \mathrm{m}^{2}$, baseline $25(\mathrm{OH}) \mathrm{D}$ concentration 
$40 \mathrm{nmol} / \mathrm{l}$ and all 3 "best" genotypes (major homozygote for rs2282679 and rs7041 and minor homozygote for rs10741657) was estimated to have a delta $25(\mathrm{OH}) \mathrm{D}$ of $77.8 \mathrm{nmol} / \mathrm{l}$, while a person with the same baseline $25(\mathrm{OH}) \mathrm{D}$ but BMI $40 \mathrm{~kg} / \mathrm{m}^{2}$ and with the "worst" genotypes (minor homozygote for rs2282679 and rs7041 and major homozygote for rs10741657) was estimated to have a delta 25(OH)D of about $19.3 \mathrm{nmol} / \mathrm{l}$.

\section{Discussion}

$\nabla$

In the present intervention study, we have found that the baseline serum $25(\mathrm{OH}) \mathrm{D}$ concentration is influenced by genetic factors, and that these factors together with BMI and the baseline $25(\mathrm{OH}) \mathrm{D}$ concentration are strong predictors of the serum $25(\mathrm{OH}) \mathrm{D}$ response to vitamin D supplementation. Humans get vitamin $D$ from the diet (fatty fish), cod liver oil, vitamin D supplements, and from endogenous production in the skin upon solar UVB exposure [2]. The serum 25(OH)D concentration is mainly the result of available vitamin $\mathrm{D}$ as substrate for 25-hydroxylation in the liver, binding and transportation in the circulation by DBP, and degradation by 24-hydroxylation and subsequent removal from the circulation [2]. It is therefore no surprise that SNPs in genes related to synthesis (DHCR7/ NADSYN1 and CYP2R1), binding and transportation (DBP/GC), and degradation (CYP24A1) affect the 25(OH)D concentration, which has been shown in several GWAS studies [11,12].

The differences we have found between major and minor homozygote's for these SNPs are very similar to those reported

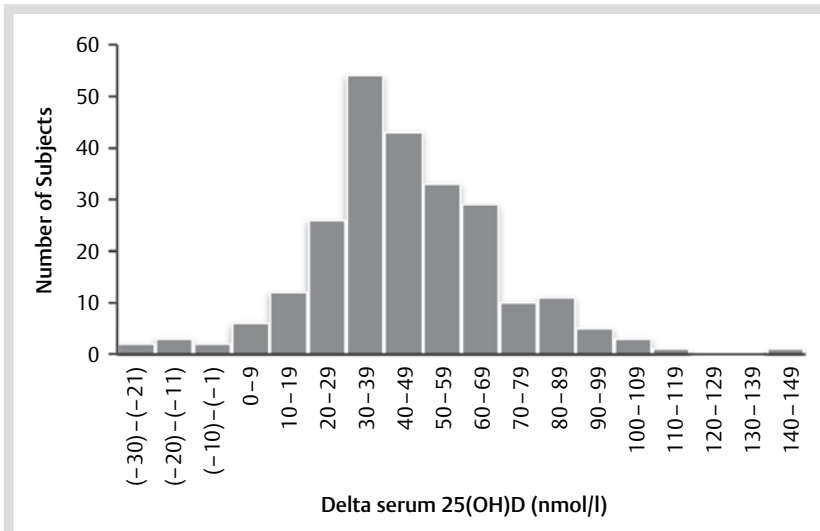

Fig. 2 The distribution in increase (12 month minus baseline value) in serum 25(OH)D concentration in subjects randomized to vitamin D. by others $[11,12,14,20,23-26]$. We have also previously published similar results based on 3 smaller RCTs where only 3 of the present SNPs (rs2282679, rs7041, rs10741657) were significantly associated with serum $25(\mathrm{OH}) \mathrm{D}$ [14].

The most remarkable genotype effect was for the SNPs in the $D B P / G C$ gene. Thus, for rs228279 the subjects with the major homozygote genotype had $19.2 \mathrm{nmol} / 1$, or $43.6 \%$, higher serum $25(\mathrm{OH}) \mathrm{D}$ concentration than those with the minor homozygote genotype. In spite of this difference, there was no significant relation with serum PTH, which is a good marker of vitamin D's biological effects [27]. However, SNPs in the DBP/GC gene are related not only to the total serum $25(\mathrm{OH}) \mathrm{D}$ concentration, but also to the serum level of DBP and/or DBP phenotype $[28,29]$. DBP exist in 6 major phenotypes, each with different binding coefficients for 25(OH)D [30,31], and accordingly, the total $25(\mathrm{OH}) \mathrm{D}$ may not accurately reflect the level of free or bioavailable (sum of free and albumin-bound) 25(OH)D [32]. If these 2 latter $25(\mathrm{OH}) \mathrm{D}$ fractions are the ones responsible for biological activity, then that could explain the lack of association between rs228279 and rs7041 and PTH. On the other hand, for the CYP24A1 SNP there was a highly significant association with serum PTH, both when analyzing all subjects at baseline as well as in the vitamin D group after 12 months. This is unlikely to be a chance finding since we have reported a similar result in a cohort of 9471 subjects [23].

Accordingly, the biological importance of genotype-associated differences in total serum 25(OH)D is uncertain and may depend on the SNP in question. This will probably first be settled when it is clarified which vitamin D metabolite [total $25(\mathrm{OH}) \mathrm{D}$, free and/or bioavailable $25(\mathrm{OH}) \mathrm{D}$, or even the mother compound vitamin $D$ ], one should measure to evaluate a subject's vitamin $D$ status. Until then, measurement of total serum 25(OH)D concentration will remain the gold standard regardless of what recommendations concerning sufficient and/or optimal serum concentrations are needed for supplementation.

It is generally assumed that an intake of $100 \mathrm{IU} /$ day leads to an increase in serum 25(OH)D of approximately $2.5 \mathrm{nmol} / \mathrm{l}$ [33]. However, the response to supplementation varies considerably from person to person resulting in a very wide distribution for serum 25(OH)D concentrations after 1 year as illustrated in $\odot$ Fig. 1. The most important predictor for the response to supplementation was in our study genetic factors. Thus, for all five SNPs the increase in serum $25(\mathrm{OH}) \mathrm{D}$ after supplementation was greatest in the genotypes with the highest $25(\mathrm{OH}) \mathrm{D}$ at baseline. This is no surprise, since genetic differences in production, transportation and degradation of $25(\mathrm{OH}) \mathrm{D}$ resulting in differ-

Table 3 Predicted increase (delta) in 25(OH)D (nmol/l) according to baseline 25(OH)D, BMI, and genetic status after supplementation with $20000 \mathrm{IU}$ per week for one year.

\begin{tabular}{|c|c|c|c|c|c|c|c|c|c|c|}
\hline \multirow[t]{2}{*}{ Variables } & \multicolumn{2}{|c|}{ BMI $22 \mathrm{~kg} / \mathrm{m}^{2}$} & \multicolumn{2}{|c|}{ BMI $25 \mathrm{~kg} / \mathrm{m}^{2}$} & \multicolumn{2}{|c|}{ BMI $30 \mathrm{~kg} / \mathrm{m}^{2}$} & \multicolumn{2}{|c|}{ BMI $35 \mathrm{~kg} / \mathrm{m}^{2}$} & \multicolumn{2}{|c|}{ BMI $40 \mathrm{~kg} / \mathrm{m}^{2}$} \\
\hline & $\begin{array}{l}\text { Best } \\
\text { genes }\end{array}$ & $\begin{array}{l}\text { Worst } \\
\text { genes }\end{array}$ & $\begin{array}{l}\text { Best } \\
\text { genes }\end{array}$ & $\begin{array}{l}\text { Worst } \\
\text { genes }\end{array}$ & $\begin{array}{l}\text { Best } \\
\text { genes }\end{array}$ & $\begin{array}{l}\text { Worst } \\
\text { genes }\end{array}$ & $\begin{array}{l}\text { Best } \\
\text { genes }\end{array}$ & $\begin{array}{l}\text { Worst } \\
\text { genes }\end{array}$ & $\begin{array}{l}\text { Best } \\
\text { genes }\end{array}$ & $\begin{array}{l}\text { Worst } \\
\text { genes }\end{array}$ \\
\hline \multicolumn{11}{|c|}{ Baseline serum 25(OH)D } \\
\hline $30 \mathrm{nmol} / \mathrm{l}$ & 81.2 & 47.5 & 77.0 & 43.3 & 70.1 & 36.4 & 63.2 & 29.5 & 62.3 & 22.6 \\
\hline $40 \mathrm{nmol} / \mathrm{l}$ & 77.8 & 44.1 & 73.7 & 40.0 & 66.8 & 33.1 & 59.9 & 26.2 & 53.0 & 19.3 \\
\hline $50 \mathrm{nmol} / \mathrm{l}$ & 74.5 & 40.8 & 70.3 & 36.6 & 63.4 & 29.7 & 56.5 & 22.8 & 49.6 & 15.9 \\
\hline $60 \mathrm{nmol} / \mathrm{l}$ & 71.1 & 37.4 & 67.0 & 33.3 & 60.1 & 26.4 & 53.2 & 19.5 & 46.3 & 12.6 \\
\hline $70 \mathrm{nmol} / \mathrm{l}$ & 67.8 & 34.1 & 63.6 & 29.9 & 56.7 & 23.0 & 49.8 & 16.1 & 42.9 & 9.2 \\
\hline
\end{tabular}

"Best genes": The genes associated with the largest increase in serum 25(OH)D concentration when giving vitamin D supplementation "Worst genes": The genes associated with the lowest increase in serum $25(\mathrm{OH}) \mathrm{D}$ concentration when giving vitamin $\mathrm{D}$ supplementation 25(OH)D: 25-Hydroxyvitamin D; BMI: Body mass index 
ences in 25(OH)D at baseline will also affect the handling of the additional vitamin D supplements. Thus, subjects with genotypes associated with low serum 25(OH)D concentrations will need a higher supplemental dose to reach a higher targeted 25(OH)D level. The exception to this was the DHCR71 SNP rs3829251, where the increase in 25(OH)D was highest in those with the genotype with the lowest baseline levels. The reason might be that this SNP is involved in conversion of 7-DHC in the skin to precursors for vitamin D production [19], and therefore probably not involved in the metabolism of exogenous vitamin $\mathrm{D}$. There are few previous reports on genetic effects on $25(\mathrm{OH}) \mathrm{D}$ response to vitamin D supplementation. In 2 recently published studies, a number of SNPs were tested for relation to $25(\mathrm{OH}) \mathrm{D}$ levels $[34,35]$. The most strongly related were the ones in the CYP2R1 gene, and in the largest study by Barry et al. where 1787 non-Hispanic whites were included, a SNP in the VDR gene was also found to affect the increase in serum 25(OH)D [35]. Furthermore, in their regression model for prediction of $25(\mathrm{OH}) \mathrm{D}$ response, Waterhouse et al. found inclusion of SNPs to be as important as personal and environmental factors [34].

In addition to genetic factors, the baseline concentration and BMI were also important for the 25(OH)D response. Thus, those with low baseline levels had the highest increase in $25(\mathrm{OH}) \mathrm{D}$ after supplementation, which could partly be ascribed to the expected regression towards the mean. It is also reasonable to assume that available vitamin $\mathrm{D}$ is metabolized slower the lower the $25(\mathrm{OH}) \mathrm{D}$ concentrations are, but in spite of these factors, those with low baseline $25(\mathrm{OH}) \mathrm{D}$ did not catch up with those who started out higher.

The serum 25(OH)D concentrations are lower in obese subjects, which could be due to lower intake of vitamin D, less sun-exposure, degradation of vitamin $\mathrm{D}$ in adipose tissue, or simply that obese subjects have a higher distribution volume for vitamin D [36]. Obese subjects also had a markedly reduced response to vitamin D supplementation in our study similar to that reported by others $[9,10,37,38]$, which supports storage and/or degradation of vitamin $\mathrm{D}$ in adipose tissue.

On the other hand, we found age, sex and calcium intake not to be important in this regard. For age, most studies report lower levels in older subjects $[39,40]$; however, this is not seen in studies from our area, Northern Norway [41]. This is most probably due to a more traditional and vitamin $\mathrm{D}$ healthy diet with a high intake of fatty fish. In other populations where the $25(\mathrm{OH}) \mathrm{D}$ level is more related to sun-exposure, the effect of age will be different since it is established that the capacity for vitamin D production in the skin is reduced with age [39]. However, our data where the increase in $25(\mathrm{OH}) \mathrm{D}$ was similar in the age groups studied, as also found by Gallagher et al. [42], may indicate that aging does not affect the absorption and metabolism of vitamin $\mathrm{D}$ from diet and supplements. We saw a slight effect of sex on baseline $25(\mathrm{OH}) \mathrm{D}$ concentration, but similar response to vitamin D supplementation, and accordingly males and females probably need similar amounts of vitamin D supplementation, which was also the conclusion in the study by Aloia et al. [43]. There are reports that the intake of calcium has a vitamin D sparing effect by reducing the serum PTH concentration resulting in less hydroxylation of $25(\mathrm{OH}) \mathrm{D}$ to the active form $1,25(\mathrm{OH})_{2} \mathrm{D}[44,45]$. This was not seen in our study, but the number of subjects taking calcium supplements was low.

The 3 important factors for the vitamin D supplementation response; baseline 25(OH)D concentrations, BMI, and genotype, are at least partly interrelated. We therefore integrated these factors (as well as the randomization status to account for the regression towards the mean) in a regression equation to predict the $25(\mathrm{OH}) \mathrm{D}$ response to a weekly dose of $20000 \mathrm{IU}$ vitamin $\mathrm{D}_{3}$. When using this equation the predicted differences between sub-groups were remarkable as illustrated in $\bullet$ Table 3. Thus, if aiming at a serum level of $>75 \mathrm{nmol} / \mathrm{l}$ by giving 20000 IU per week, all subjects with BMI of $22 \mathrm{~kg} / \mathrm{m}^{2}$ or "optimal" genetic status would reach the target regardless of other factors. On the other hand, hardly any of the subjects with morbid obesity $\left(\mathrm{BMI} \geq 35 \mathrm{~kg} / \mathrm{m}^{2}\right)$, the "worst" genes, and a baseline serum $25(\mathrm{OH}) \mathrm{D}$ of $<50 \mathrm{nmol} / 1$ would reach the target. In this context, it should be remembered that the frequency of the "best" alleles are higher than for those associated with low serum 25(OH)D. However, at the population level subjects with the "worst" alleles still amount to millions of subjects, and in our study $12.4 \%$ had 1 year serum 25(OH)D levels $<75 \mathrm{nmol} / \mathrm{l}$. Also, some subjects had a remarkably high $25(\mathrm{OH}) \mathrm{D}$ response and $9.1 \%$ had serum $25(\mathrm{OH}) \mathrm{D}>140 \mathrm{nmol} / \mathrm{l}$ after 1 year, which may not be favorable [6-8].

The $25(\mathrm{OH}) \mathrm{D}$ response to supplementation can be predicted by baseline concentration and BMI, which is inexpensive, but also needs genotyping, which is costly. Therefore, for the individual subject the most easiest way to tailor the vitamin $\mathrm{D}$ dose would be to simply measure the responding $25(\mathrm{OH}) \mathrm{D}$ concentration. However, for general advice on supplementation it is important to know that some subgroups need substantially more vitamin D to reach the desired 25(OH)D target. In this context, it should also be mentioned that at present we do not know what is an adequate $25(\mathrm{OH}) \mathrm{D}$ concentration, and recommendations differ with $50 \%$; the Institute of Medicine finding no proof for additional benefit with levels higher than $50 \mathrm{nmol} / \mathrm{l}$ [4], whereas guidelines from the Endocrine Society recommend a level of $75 \mathrm{nmol} / \mathrm{l}$ [3]. Furthermore, it is not known how large the therapeutic window for vitamin $\mathrm{D}$ supplementation is, and the $\mathrm{U}$ - or J-shaped relation between serum 25(OH)D and health outcomes with possible harmful effects with the higher 25(OH)D concentrations are based on association studies only.

Our study has some limitations. The study population is homogenous, but the results cannot be generalized as all participants had IGT and/or IFG, live in Northern Norway at latitude of $69^{\circ}$ with low UVB solar exposure, and almost all were Caucasians. Furthermore, we did not include data on sun exposure, skin darkness, and physical activity, and we did not measure the free fraction of serum $25(\mathrm{OH}) \mathrm{D}$, which might be the biologically active one. Nor did we measure the 25(OH)D catabolite 24,25 -dihydroxyvitamin $\mathrm{D}\left[24,25(\mathrm{OH})_{2} \mathrm{D}\right]$ which could have been of importance since it has been reported that the $24,25(\mathrm{OH})_{2} \mathrm{D} / 25(\mathrm{OH}) \mathrm{D}$ ratio predicts the $25(\mathrm{OH}) \mathrm{D}$ response to vitamin D supplementation [46].

However, the study also has strength, as we included a large group of subjects, had predefined a limited number of SNPs to evaluate, and were able to create an applicable regression equation for predicting response to vitamin D supplementation.

In conclusion, we do know that lifestyle is the most important determinant for 25(OH)D concentration. However, it is difficult to change an unhealthy lifestyle, and if the present recommendations regarding adequate $25(\mathrm{OH}) \mathrm{D}$ concentrations are correct, a considerable number of subjects need vitamin D supplementation. There are large individual differences in response to supplementation, and this needs to be taken into account when giving general advice on vitamin $\mathrm{D}$ supplementation. 


\section{Authors' Contribution}

R.J. is the guarantor of this work and had full access to all the data in the study and takes responsibility for the integrity of the data and the accuracy of the data analysis. S.T.S. researched data and wrote the manuscript; M.Y.S.H. and R.J. researched data; O.M.F. contributed to the analyses of serum 25-(OH)D; R.M.J. contributed to the regression equation; all authors contributed to the discussion, review, and editing of the manuscript.

\section{Acknowledgements}

This study was supported by grants from The North Norway Regional Health Authority, The Norwegian Diabetes Association, The University of Tromsø, The Research Council of Norway, and The Novo Nordisk foundation. The superb assistance from the staff at the Clinical Research Unit and the Department of Medical Biochemistry at the University Hospital of North Norway, is greatly acknowledged. The authors also thank the Tromsø Study for providing data necessary for the inclusion of the participants.

\section{Conflict of Interest}

The authors declare that they have no conflicts of interest in the authorship or publication of this contribution.

\section{References}

1 Rosen CJ, Adams JS, Bikle DD, Black DM, Demay MB, Manson JE, Murad $M H$, Kovacs CS. The nonskeletal effects of vitamin D: an Endocrine Society scientific statement. Endocr Rev 2012; 33: 456-492

2 Hossein-Nezhad A, Holick MF. Vitamin d for health: a global perspective. Mayo Clinic Proceed Mayo Clinic 2013; 88: 720-755

3 Holick MF, Binkley NC, Bischoff-Ferrari HA, Gordon CM, Hanley DA, Heaney RP, Murad MH, Weaver CM. Evaluation, treatment, and prevention of vitamin D deficiency: an Endocrine Society clinical practice guideline. J Clin Endocrinol Metab 2011; 96: 1911-1930

4 Institute of Medicine Committee to Review Dietary Reference Intakes for Vitamin D, Calcium. The National Academies Collection: Reports funded by National Institutes of Health. In: Ross AC, Taylor CL, Yaktine AL, Del Valle HB (eds.). Dietary Reference Intakes for Calcium and Vitamin D. Washington (DC): National Academies Press (US). National Academy of Sciences, 2011

5 van Schoor NM, Lips P. Worldwide vitamin D status. Best Pract Res Clin Endocrinol Metab 2011; 25: 671-680

6 Sempos CT, Durazo-Arvizu RA, Dawson-Hughes B, Yetley EA, Looker AC, Schleicher RL, Cao G, Burt V, Kramer H, Bailey RL, Dwyer JT, Zhang X, Gahche J, Coates PM, Picciano MF. Is there a reverse J-shaped association between 25-hydroxyvitamin D and all-cause mortality? Results from the U.S. nationally representative NHANES. J Clin Endocrinol Metab 2013; 98: 3001-3009

7 Amrein K, Quraishi SA, Litonjua AA, Gibbons FK, Pieber TR, Camargo CA $J r$, Giovannucci E, Christopher KB. Evidence for a U-shaped relationship between prehospital vitamin D status and mortality: a cohort study. J Clin Endocrinol Metab 2014; 99: 1461-1469

8 Durup D, Jorgensen HL, Christensen J, Schwarz P, Heegaard AM, Lind $B$. A reverse J-shaped association of all-cause mortality with serum 25-hydroxyvitamin D in general practice: the CopD study. J Clin Endocrinol Metab 2012; 97: 2644-2652

9 Gallagher JC, Yalamanchili V, Smith LM. The effect of vitamin D supplementation on serum $25(\mathrm{OH}) \mathrm{D}$ in thin and obese women. J Steroid Biochem Mol Biol 2013; 136: 195-200

10 Jorde R, Sneve M, Emaus N, Figenschau Y, Grimnes G. Cross-sectional and longitudinal relation between serum 25 -hydroxyvitamin $D$ and body mass index: the Tromso study. Eur J Nutr 2010; 49: 401-407

11 Wang TJ, Zhang F, Richards JB, Kestenbaum B, van Meurs JB, Berry D, Kiel DP, Streeten EA, Ohlsson C, Koller DL, Peltonen L, Cooper JD, O'Reilly $P F$, Houston DK, Glazer NL, Vandenput L, Peacock M, Shi J, Rivadeneira F, McCarthy MI, Anneli P, de Boer IH, Mangino M, Kato B, Smyth DJ,
Booth SL, Jacques PF, Burke GL, Goodarzi M, Cheung CL, Wolf M, Rice $K$, Goltzman D, Hidiroglou N, Ladouceur M, Wareham NJ, Hocking $L J$, Hart D, Arden NK, Cooper C, Malik S, Fraser WD, Hartikainen AL, Zhai G, Macdonald HM, Forouhi NG, Loos RJ, Reid DM, Hakim A, Dennison E, Liu Y, Power C, Stevens HE, Jaana L, Vasan RS, Soranzo N, Bojunga $J$, Psaty BM, Lorentzon M, Foroud T, Harris TB, Hofman A, Jansson JO, Cauley JA, Uitterlinden AG, Gibson Q Jarvelin MR, Karasik D, Siscovick DS, Econs MJ, Kritchevsky SB, Florez JC, Todd JA, Dupuis J, Hypponen E, Spector TD. Common genetic determinants of vitamin D insufficiency: a genome-wide association study. Lancet 2010; 376: 180-188

12 Ahn J, Yu K, Stolzenberg-Solomon R, Simon KC, McCullough ML, Gallicchio L, Jacobs EJ, Ascherio A, Helzlsouer K, Jacobs KB, Li Q Weinstein SJ, Purdue M, Virtamo J, Horst R, Wheeler W, Chanock S, Hunter DJ, Hayes $R B$, Kraft $P$, Albanes $D$. Genome-wide association study of circulating vitamin D levels. Human Mol Genet 2010; 19: 2739-2745

$13 \mathrm{Fu}$ L, Yun F, Oczak M, Wong BY, Vieth R, Cole DE. Common genetic variants of the vitamin D binding protein (DBP) predict differences in response of serum 25-hydroxyviamin D [25(OH)D] to vitamin D supplementation. Clin Biochem 2009; 42: 1174-1177

14 Didriksen A, Grimnes G, Hutchinson MS, Kjaergaard M, Svartberg J, Joakimsen RM, Jorde $R$. The serum 25-hydroxyvitamin D response to vitamin D supplementation is related to genetic factors, BMI, and baseline levels. Eur J Endocrinol 2013; 169: 559-567

15 Nimitphong H, Saetung S, Chanprasertyotin S, Chailurkit LO, Ongphiphadhanakul $B$. Changes in circulating 25 -hydroxyvitamin D according to vitamin $\mathrm{D}$ binding protein genotypes after vitamin $\mathrm{D}(3)$ or $\mathrm{D}(2)$ supplementation. Nutr J 2013; 12: 39

16 Sollid ST, Hutchinson MY, Fuskevag OM, Figenschau Y, Joakimsen RM, Schirmer H, Njolstad I, Svartberg J, Kamycheva E, Jorde R. No Effect of High-Dose Vitamin D Supplementation on Glycemic Status or Cardiovascular Risk Factors in Subjects With Prediabetes. Diabetes Care 2014; 37: 2123-2131

17 Definition and diagnosis of diabetes mellitus and intermediate hyperglycemia: report of a WHO/IDF consultation. World Health Organization 2006. Available online: http://www.who.int/diabetes/publications/ diagnosis_diabetes2006/en/

18 Hutchinson MS, Grimnes G, Joakimsen RM, Figenschau Y, Jorde R. Low serum 25-hydroxyvitamin D levels are associated with increased allcause mortality risk in a general population: the Tromso study. Eur J Endocrinol 2010; 162: 935-942

19 Berry D, Hypponen E. Determinants of vitamin D status: focus on genetic variations. Curr Opin Nephrol Hypertens 2011; 20: 331-336

20 Sinotte M, Diorio C, Berube S, Pollak M, Brisson J. Genetic polymorphisms of the vitamin $\mathrm{D}$ binding protein and plasma concentrations of 25-hydroxyvitamin D in premenopausal women. Am J Clin Nutr 2009; 89: 634-640

21 Rodriguez S, Gaunt TR, Day IN. Hardy-Weinberg equilibrium testing of biological ascertainment for Mendelian randomization studies. Am J Epidemiol 2009; 169: 505-514

22 Gaunt TR, Rodriguez S, Day IN. Cubic exact solutions for the estimation of pairwise haplotype frequencies: implications for linkage disequilibrium analyses and a web tool 'CubeX'. BMC Bioinform 2007; 8: 428

23 Jorde R, Schirmer H, Wilsgaard T, Joakimsen RM, Mathiesen EB, Njolstad I, Lochen ML, Figenschau Y, Berg JP, Svartberg J, Grimnes G. Polymorphisms related to the serum 25-hydroxyvitamin D level and risk of myocardial infarction, diabetes, cancer and mortality. The Tromso Study. PloS One 2012; 7: e37295

24 Cheung CL, Lau KS, Sham PC, Tan KC, Kung AW. Genetic variant in vitamin D binding protein is associated with serum 25-hydroxyvitamin $\mathrm{D}$ and vitamin D insufficiency in southern Chinese. J Human Genet 2013; 58: 749-751

25 Pekkinen M, Saarnio E, Viljakainen HT, Kokkonen E, Jakobsen J, Cashman $K$, Makitie $O$, Lamberg-Allardt $C$. Vitamin D binding protein genotype is associated with serum 25-hydroxyvitamin D and PTH concentrations, as well as bone health in children and adolescents in Finland. PloS One 2014; 9: e87292

26 Nissen J, Rasmussen LB, Ravn-Haren G, Andersen EW, Hansen B, Andersen $R$, Mejborn $H$, Madsen $K H$, Vogel $U$. Common variants in CYP2R1 and GC genes predict vitamin D concentrations in healthy Danish children and adults. PloS One 2014; 9: e89907

27 Steingrimsdottir L, Gunnarsson O, Indridason OS, Franzson L, Sigurdsson G. Relationship between serum parathyroid hormone levels, vitamin D sufficiency, and calcium intake. JAMA 2005; 294: 2336-2341

28 Powe CE, Evans MK, Wenger J, Zonderman AB, Berg AH, Nalls M, Tamez $H$, Zhang D, Bhan I, Karumanchi SA, Powe NR, Thadhani R. Vitamin D-binding protein and vitamin D status of black Americans and white Americans. N Engl J Med 2013; 369: 1991-2000 
29 Moy KA, Mondul AM, Zhang H, Weinstein SJ, Wheeler W, Chung CC, Mannisto S, Yu K, Chanock SJ, Albanes D. Genome-wide association study of circulating vitamin D-binding protein. Am J Clin Nutr 2014; 99: $1424-1431$

30 Arnaud J, Constans J. Affinity differences for vitamin D metabolites associated with the genetic isoforms of the human serum carrier protein (DBP). Human Genet 1993; 92: 183-188

31 Lauridsen $A L$, Vestergaard $P$, Nexo E. Mean serum concentration of vitamin D-binding protein (Gc globulin) is related to the Gc phenotype in women. Clin Chem 2001; 47: 753-756

32 Chun RF, Peercy BE, Orwoll ES, Nielson CM, Adams JS, Hewison M. Vitamin D and DBP: The free hormone hypothesis revisited. J Steroid Biochem Mol Biol 2014; 144 (Pt A): 132-137

33 Romagnoli E, Pepe J, Piemonte S, Cipriani C, Minisola S. Management of endocrine disease: value and limitations of assessing vitamin D nutritional status and advised levels of vitamin D supplementation. Eur J Endocrinol 2013; 169: R59-R69

34 Waterhouse M, Tran B, Armstrong BK, Baxter C, Ebeling PR, English DR, Gebski V, Hill C, Kimlin MG, Lucas RM, Venn A, Webb PM, Whiteman $D C$, Neale RE. Environmental, personal and genetic determinants of response to vitamin D supplementation in older adults. J Clin Endocrinol Metab 2014; 99: E1332-E1340

35 Barry EL, Rees JR, PeacockJL, Mott LA, Amos CI, Bostick RM, Figueiredo JC, Ahnen DJ, Bresalier RS, Burke CA, Baron JA. Genetic Variants in CYP2R1, CYP24A1 and VDR Modify the Efficacy of Vitamin D Supplementation for Increasing Serum 25-Hydroxyvitamin D Levels in a Randomized Controlled Trial. J Clin Endocrinol Metab 2014; E2133-E2137

36 Vanlint S. Vitamin D and obesity. Nutrients 2013; 5: 949-956

37 Gallagher JC, Sai A, Templin T $2^{\text {nd }}$, Smith L. Dose response to vitamin $D$ supplementation in postmenopausal women: a randomized trial. Ann Internal Med 2012; 156: 425-437
38 Dhaliwal R, Mikhail M, Feuerman M, Aloia JF. The Vitamin D Dose Response in Obesity. Endocr Pract 2014; 20: 1258-1264

39 Hill TR, Aspray TJ, Francis RM. Vitamin D and bone health outcomes in older age. Proceed Nutr Soc 2013; 72: 372-380

40 van der Wielen RP, Lowik MR, van den Berg H, de Groot LC, Haller J, Moreiras $O$, van Staveren WA. Serum vitamin D concentrations among elderly people in Europe. Lancet 1995; 346: 207-210

41 Jorde R, Figenschau $Y$, Emaus N, Hutchinson M, Grimnes G. Serum 25-hydroxyvitamin D levels are strongly related to systolic blood pressure but do not predict future hypertension. Hypertension 2010; 55: 792-798

42 Gallagher JC, Jindal PS, Smith LM. Vitamin D supplementation in young White and African American women. J Bone Min Res 2014; 29: $173-181$

43 Aloia JF, Patel M, Dimaano R, Li-Ng M, Talwar SA, Mikhail M, Pollack S, Yeh JK. Vitamin D intake to attain a desired serum 25-hydroxyvitamin D concentration. Am J Clin Nutr 2008; 87: 1952-1958

44 Lips $P$. Interaction between vitamin D and calcium. Scand J Clin Lab Invest Suppl 2012; 243: 60-64

45 Gallagher JC, Peacock M, Yalamanchili V, Smith LM. Effects of vitamin D supplementation in older African American women. J Clin Endocrinol Metab 2013; 98: 1137-1146

46 Wagner D, Hanwell HE, Schnabl K, Yazdanpanah M, Kimball S, Fu L, Sidhom $G$, Rousseau D, Cole DE, Vieth $R$. The ratio of serum 24,25-dihydroxyvitamin $\mathrm{D}(3)$ to 25 -hydroxyvitamin $\mathrm{D}(3)$ is predictive of 25-hydroxyvitamin $\mathrm{D}(3)$ response to vitamin $\mathrm{D}(3)$ supplementation. J Steroid Biochem Mol Biol 2011; 126: 72-77 